\title{
SHRIMP U-Pb dating of perovskite from kimberlites of the Siberian platform (Verhnemunskoe and Alakite-Marhinskoe fields)
}

\author{
Elena N. Lepekhina ${ }^{1}$, Anatoly Ya. Rotman ${ }^{2}$, Anton V. Antonov ${ }^{1}$, Sergey A. Sergeev ${ }^{1}$ \\ ${ }^{1}$ Centre of Isotopic Research, All-Russian Geological Research Institute, St.-Petersburg, Russia, \\ ${ }^{2}$ YaNIGP TsNIGRI Alrosa Co. Ltd, Mirny, Russia \\ (Elena_Lepekhina@vsegei.ru)
}

Perovskite is a relatively common melt-precipitated mineral of kimberlite and related mantle rocks (Chakmouradian, 2000). Besides perovskite is also a well-known mineral which has proved amenable to U$\mathrm{Pb}$ dating of the kimberlite emplacement. The main problems and promises of U-Pb SIMS dating of perovskite are detail described in many articles (Ireland, 1990, Kinny, 1997,Williams, 1998,).

\section{Method}

SHRIMP analyses of perovskites were performed at Centre of Isotopic Research (VSEGEI, Saint Petersburg, Russia). The procedure for SIMS U-Pb perovskite analysis is similar to that described by Ireland, 1990. Blocks of kimberlite about $0.5 \mathrm{~cm}^{2}$ were selected and mounted in epoxy resin (probe mount) together with analytical standard and polished.

As a standard we have used perovskite from skarn rocks of the Tazheran complex, Lake Baikal area.

Tazheran perovskite was previously analysed by classical U-Pb isotope ID-TIMS method. Obtained U$\mathrm{Pb}$ age corresponds to $458 \pm 5 \mathrm{Ma}$, that is in a good agreement with other labs' data. While our SHRIMP-II dating of this perovskite gives $465 \pm 15$ Ma with a probability of concordance -0.7 .

\section{Samples}

We have analysed 30 single perovskite grains from the three kimberlite pipes: Novinka and Poiskovaya pipes from the Verhnemunskoe field and Yubileinaya pipe of Alakite-Marhinskoe field. Sampled rocks represent hypabyssal facies of massive kimberlite with porphyritic structure. In studied samples microcrystalline oxide minerals are mainly presented by spinel $\left(\sim 30-40 \quad\right.$ wt. $\left.\% \quad \mathrm{Cr}_{2} \mathrm{O}_{3}\right)$, perovskite, titanomagnetite and ilmenite.

The kimberlites from Verhnemynskoe field is distinguished by high and prevailing to other oxide minerals perovskite content in groundmass (up to 10 vol.\%). Perovskite crystallized as euhedral and subhedral, rounded crystals from 10 to $100 \mu \mathrm{m}$ in size (fig. 2). Perovskite was found in investigated kimberlites in diverse paragenesis. The most of perovskite crystals are randomly disseminated throughout the serpentine-calcite mesostasis (Fig. 1A.). Also perovskite crystals form "necklaces" around earlier-formed olivine and Cr-spinel phenocrysts.

In the same time, titanomagnetites with ilmenite disseminations are rimmed perovskite crystals. Studied perovskite is stoichiometrically close to the $\mathrm{CaTiO}_{3}$ end-member composition with slight enrichment in $\mathrm{Ce}_{2} \mathrm{O}_{3}$ (up to $3 \mathrm{wt}$ \% $\%$ for core and up to $1 \mathrm{wt} . \%$ for rim).

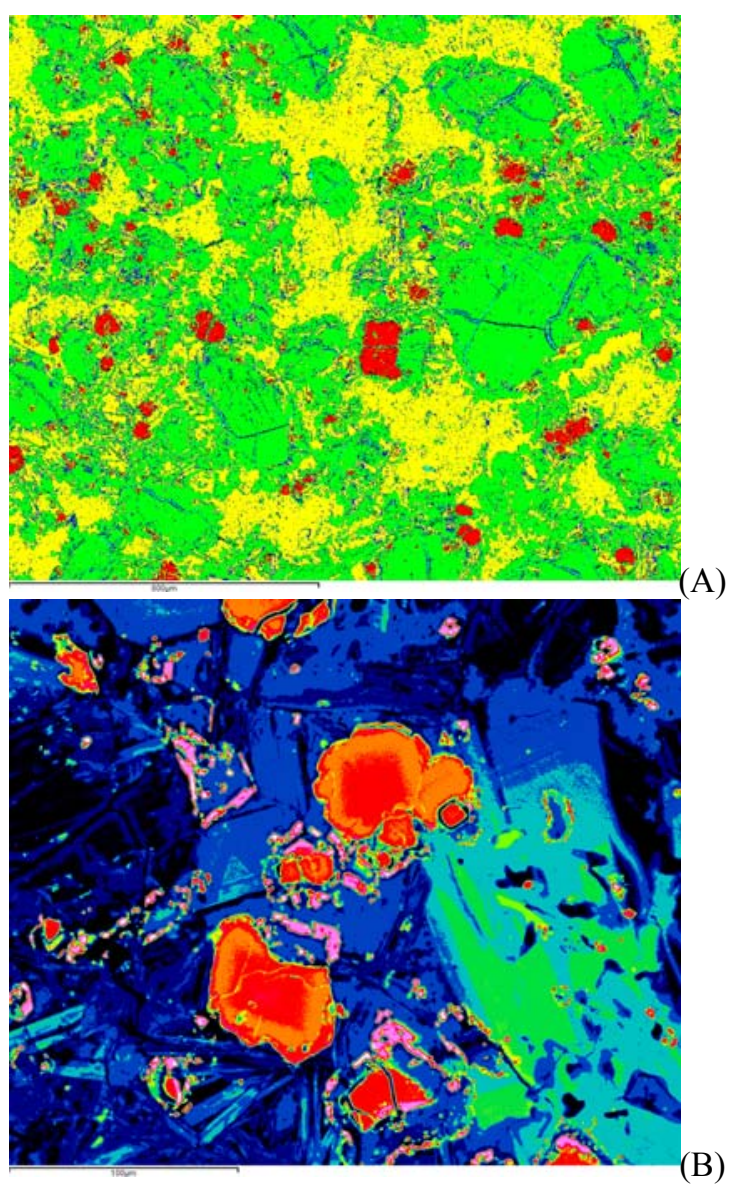

Fig. 1. False-colour back-scattered electron (BSE) images of perovskite in kimberlite. The images were acquired with the INCA Energy software package using CamScan 2500 MX SEM. A. Novinka pipe. Red - perovskite and spinel, green - olivine (serpentine), yellow - calcite. B. Poiskovaya pipe. Red-orange zonal perovskite, pink - Ti-magnetite, pale blue phlogopite, dark blue - calcite. 


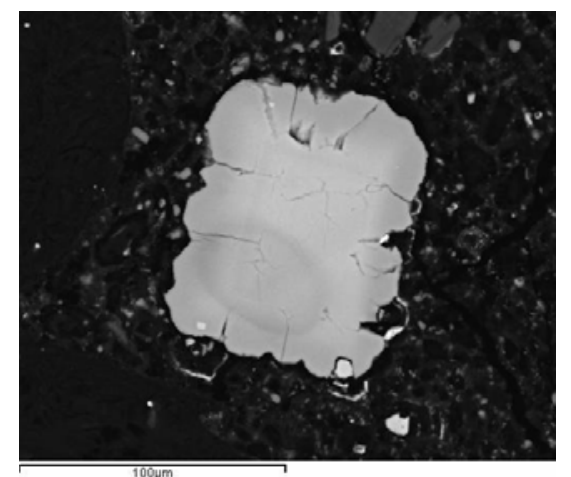

Fig. 2. Backscattered electron image of perovskite from Novinka pipe kimberlite with SHRIMP spot crater.

\section{Results}

Ten grains of perovskite from polished sections for each of 3 pipe were analysed.

The obtained $\mathrm{U}-\mathrm{Pb}$ data, uncorrected for common $\mathrm{Pb}$, were plotted on a Tera-Wasserburg diagram, with a regression analysis to common $\mathrm{Pb}$ composition $(207 \mathrm{~Pb} / 206 \mathrm{~Pb}=0.836)$ (figure 3$)$.

The age of a perovskite from Novinka pipe is $355 \pm 11$ $\mathrm{Ma}(\mathrm{WSWD}=1.7$ ), from Poiskovaya pipe is $357 \pm 13 \mathrm{Ma}$ $(\mathrm{MSWD}=1.9)$ and from Yubileinaya pipe is $356 \pm 7$ $(\mathrm{MSWD}=1.9) \mathrm{Ma}$.

The present U-Pb perovskite ages of studied kimberlite pipes from Verhnemunskoe and Alakite-Marhinskoe fields are very close and fall within the late Devonian early Carboniferous in accordance with geological constraints and show good agreement with earlier obtained age estimates measured by different isotope techniques (Vasilenko, 2000).

\section{Reference}

Chakmouradian, A.R, Mitchell, R.H., 2000. Occurrence, alteration patterns and compositional. variation of perovskite in kimberlites. Can Mineral, 38, 975994.

Ireland, T.R., Compston, W., Williams, I.S. and Wendt, I., 1990. U- $\mathrm{Th}-\mathrm{Pb}$ systematics of individual perovskite grains from the Allende and Murchison carbonaceous chondrites. Earth Planet. Sci. Lett., 101, 379-387.

Kinny, P. D., Griffin, B.J. et al., 1997. SHRIMP U-Pb ages of perovskite and zircon from Yakutian kimberlites, Russ. Geol. Geophys. 38, 97-105.

Stacey J.S., Kramers J.D., 1975. Approximation of terrestrial lead isotope evolution by a two-stage modal. Earth. Planet. Sci. Lett.,. 26, 207-221.

Vasilenko, V. B et al., 2000. Geodinamical control of kimberlitic filds distribution (Central and North parts of Yakutian kimberlite province). Vestnik Voronezhskogo University, 9, 7-25.

Williams, I.S., 1998. U-Th-Pb Geochronology by Ion Microprobe. In: McKibben, M.A., Shanks III, W.C. and Ridley, W.I. (eds), Applications of microanalytical techniques to understanding mineralizing processes, Reviews in Economic Geology, 7, 1-35.
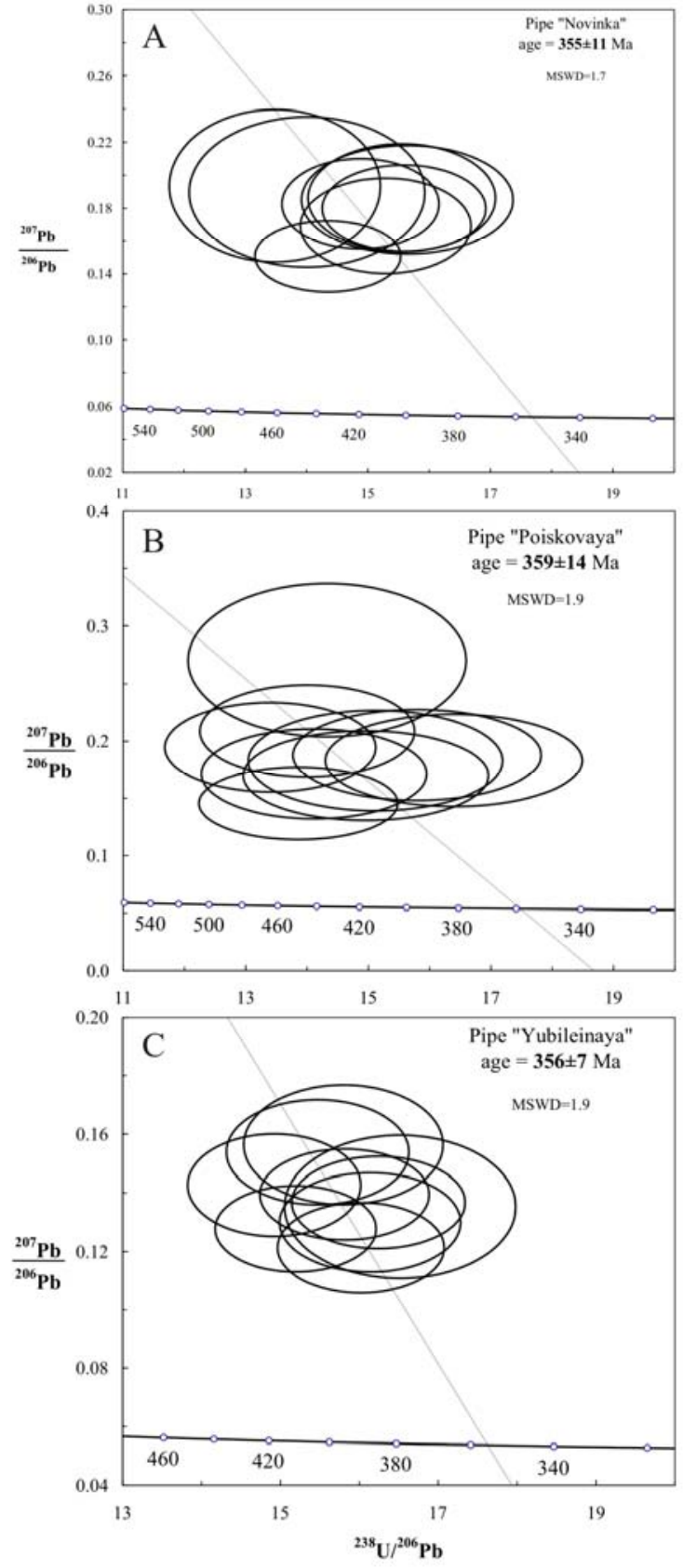

Fig. 3. U-Pb SHRIMP perovskite data plotted on a Tera-Wasserburg concordia diagram. A. Novinka pipe, B. Poiskovaya pipe and C. Yubileinaya pipe.

Analitical results are shown as one-sigma error ellipses, plotted as total ratios, uncorrected for common $\mathrm{Pb}$. Solid line indicates mixing trend between radiogenic lead and common lead of present-day composition $\left({ }^{207} \mathrm{~Pb} /{ }^{206} \mathrm{~Pb}=0.836\right.$ (Stacey, 1975)). 